\title{
DETERMINE THE EFFECT OF CAPITAL, LABOR, AND WORKING HOURS ON MERCHANT INCOME IN SURABAYA PUNCAK PERMAI MODERN MARKET IN 2019
}

\author{
Renta Yustie*1 \\ Diah Ayu Retnowati ${ }^{2}$
}

${ }^{1,2}$ Fakultas Ekonomi dan Bisnis, Universitas Wijaya Kusuma Surabaya, Indonesia

\begin{abstract}
The purpose of this study is to determine the effect of capital, labor, and working hours on merchant income in Surabaya Puncak Permai Modern Market in 2019. The data used is the Cross Section with a sample size of 78. To analyze the authors use the method of multiple linear regression with the program eviews 6.0. partially the results of the real-level regression ( $\alpha=10 \%$ ) capital significantly influence the income of traders with a positive coefficient of 0.615779 and probability 0.0000 , labor has a significant effect on trader income with a positive coefficient of 2436698. and probability 0.0000, working hours does not significantly influence the income of traders with a positive coefficient of 515060.5 and a probability of 0.3232 . Simultaneously the results of the study indicate that the variables of capital, labor and working hours have a significant effect on merchant income. With a F-Statistical probability value of 0.0000 . This means that capital and labor have a positive influence on merchant income, while working hours have no significant effect on merchant income.
\end{abstract}

Keyword: Income, Capital, Labor, Working Hours, Cross Section

\section{ABSTRAK}

Tujuan dari penelitian ini yaitu untuk mengetahui pengaruh modal, tenaga kerja, dan jam kerja terhadap pendapatan pedagang di Pasar Modern Puncak Permai Surabaya tahun 2019. Data yang digunakan adalah Cross Section dengan jumlah sampel sebanyak 78. Untuk menganalisis penulis menggunakan metode regresi linear berganda dengan program eviews 6.0. secara parsial hasil regresi taraf nyata ( $\alpha=10 \%)$ modal berpengaruh signifikan terhadap pendapatan pedagang dengan koefisien positif sebesar 0,615779 dan probabilitas 0,0000, tenaga kerja berpengaruh signifikan terhadap pendapatan pedagang dengan koefisien positif sebesar 2436698. dan probabilitas 0,0000, jam kerja tidak berpengaruh signifikan terhadap pendapatan pedagang dengan koefisien positif sebesar 515060,5 dan probabilitas 0,3232. Secara simultan hasil dari penelitian menunjukkan bahwa variabel modal, tenaga kerja dan jam kerja berpengaruh signifikan terhadap pendapatan pedagang. Dengan nilai probabilitas F-Statistik 0,0000. Hal ini berarti modal dan tenaga kerja memberikan pengaruh yang positif terhadap pendapatan pedagang, sedangkan jam kerja tidak berpengaruh signifikan terhadap pendapatan pedagang.

Kata Kunci: Pendapatan, Modal, Tenaga Kerja, Jam Kerja, Cross Section

\section{RIWAYAT ARTIKEL}

Tanggal Masuk: 3 April 2020 Tanggal Direvisi: 30 Mei 2020

Tanggal Diterima: 10 Juni 2020 Tersedia Online: 25 Juni 2020

${ }^{*}$ Korespondensi:

Renta Yustie

E-mail:

rentayustie@uwks.ac.id 


\section{Pendahuluan}

Perkembangan ekonomi Indonesia dapat diukur dengan bangkitnya pusat-pusat dari perdagangan. Keberadaan pusat perdagangan dibagi menjadi dua bagian, pasar tradisional dan pasar modern yang merupakan indikator aktivitas ekonomi masyarakat disuatu daerah. Saat ini, orang-orang berpenghasilan tinggi dan gaya hidup modern lebih suka berbelanja di pasar modern ketimbang pasar tradisional. Pasar Modern Puncak permai adalah salah satu pasar modern yang ada di Surabaya Barat yang terletak di Jalan Raya Darmo Permai. Pasar ini sama layaknya pasar tradisional pada umumnya tetapi konsepnya modern sehingga banyak masyarakat yang berkunjung disana. Pasar ini tertata rapi dan bersih, tidak terlihat sampah berserakan di sekitar kios pasar, barang dagangannya yang masih segar sehingga membuat pasar tradisional ini lain dengan pasar tradisional lainnya yang identik dengan kesan kumuh dan bau nya.

Ketika memulai usaha berdagang, modal adalah faktor yang sangat penting dalam berdagang. Untuk pertama memulai usaha berdagang, pedagang harus memiliki tempat berdagang. Modal adalah faktor pendukung penting bagi pedagang untuk melakukan bisnis mereka. Ukuran modal yang digunakan dalam biaya operasional pasti akan dapat mempengaruhi pendapatan pedagang. Modal adalah dana yang digunakan sebagai sarana pembiayaan semua jenis aset yang dapat digunakan secara langsung atau tidak langsung dalam proses produksi guna dapat meningkatkan output.

Penerapan tenaga kerja juga dapat memberi peningkatan jumlah pendapatan. Dengan adanya pekerja akan memberikan layanan yang lebih baik kepada konsumen, baik dari segi kualitas maupun dari segi kuantitas layanan. Dengan layanan yang lebih baik, akan dapat menarik lebih banyak pelanggan dan juga meningkatkan pendapatan. Selain modal dan juga tenaga kerja, namun tingkat pendapatan dari pedagang juga tergantung pada jam kerja.Jam kerja adalah waktu yang dibutuhkan pedagang untuk menjual barang dagangnya dalam sehari. Jika semakin padat jam kerja yang digunakan, maka akan semakin menguntungkan.

Pedagang adalah pemain ekonomi sangat berdampak pada sektor perdagangan karena kontribusi mereka adalah sebagai perantara dari produsen ke konsumen. Kesejahteraan pedagang dapat dilihat dari pendapatannya, sehingga faktor-faktor yang memengaruhi pendapatan para pedagang dipertimbangkan untuk menstabilkan pendapatan pedagang dan meningkatkan kesejahteraannya.

Pasar Modern Puncak Permai yaitu yang berlokasi di Jalan Raya Darmo Permai III, Sukomanunggal, terletak tepat di Kecamatan Sukomanunggal, Kota Surabaya. Pasar ini menghadirkan suasana belanja baru yang nyaman. Bangunannya juga didesain secara fungsional, dengan cara menerapkan gaya yang modern dan minimalis. Meskipun tidak menggunakan pendingin udara, sirkulasi udara di pasar modern ini didesain dengan baik sehingga tidak terasa sesak dan sempit. Dekat pasar ini terdapat kawasan ruko dengan gaya desain senada. Pasar Puncak Permai ini di dalam pasar terdapat banyak pedagang bahan makanan segar seperti sayuran, daging, buah dan sembako. Kios-kios tersebut dikelompokkan sesuai dengan jenis barang yang diperdagangkan. 
Tabel 1: Pemetaan Data

\begin{tabular}{|c|c|}
\hline Jenis Dagangan & Jumlah Pedagang \\
\hline Sayur-sayuran & 94 \\
\hline Daging & 57 \\
\hline Ayam & 47 \\
\hline Ikan & 42 \\
\hline Sembako & 38 \\
\hline Makanan & 35 \\
\hline Pakaian & 17 \\
\hline PeralatanRumahTangga & 13 \\
\hline Kosmetik & 7 \\
\hline Jumlah & 350 \\
\hline
\end{tabular}

\section{Rumusan Masalah}

Rumusan masalah yang ada pada penelitian ini adalah:

1. Apakah modal secara parsial dapat mempengaruhi besaran pendapatan pedagang di Pasar Modern Puncak Permai Tahun 2019?

2. Apakah tenaga kerja secara parsial dapat mempengaruhi pada tingkat pendapatan pedagang di Pasar Modern Puncak Permai Tahun 2019?

3. Apakah jam kerja secara parsial dapat mempengaruhi pendapatan pedagang di Pasar Modern Puncak Permai di Tahun 2019?

4. Apakah modal, tenaga kerja, dan jam kerja secara simultan bisa mempegaruhi pendapatan pedagang di Pasar Modern Puncak Permai Tahun 2019?

\section{Tujuan Penelitian}

Tujuan dari penelitian ini adalah:

1. Untuk menguji dan menganalisis apakah modal secara parsial bisa mempengaruhi pada pendapatan pedagang di Pasar Modern Puncak Permai Tahun 2019.

2. Untuk menguji dan menganalisis apakah tenaga kerja secara parsial dapat mempengaruhi pendapatan pedagang di Pasar Modern Puncak Permai Tahun 2019.

3. Untuk menguji dan menganalisis apakah jam kerja secara parsial mempengarruhi pendapatan pedagang di Pasar Modern Puncak Permai Tahun 2019.

4. Untuk menguji dan menganalisis apakah modal, tenaga kerja, dan juga jam kerja secara simultan dapat mempengaruhi pendapatan pedagang di Pasar Modern Puncak Permai Tahun 2019.

\section{Telaah Literatur}

Modal adalah segala bentuk kekayaan yang bisa digunakan secara langsung atau tidak langsung dalam proses produksi untuk dapat meningkatkan output. Dalam pengertian ekonomi modal, yaitu barang atau uang, ditambah faktor produksi tanah dan tenaga kerja, 
menciptakan barang dan jasa baru. Modal adalah input (faktor produksi) dan sangat penting dalam menentukan tingkat pendapatan. Menurut Riyanto (1998), modal adalah hasil produksi yang digunakan kembali untuk tahap produksi selanjutnya. Dalam perkembangannya modal ditekankan dalam nilai, daya beli atau bahkan kekuatan untuk menggunakan barang modal. Modal terdiri dari dua jenis, yaitu modal pinjaman atau utang dan modal sendiri. Modal juga dapat didefinisikan sebagai suatu faktor penting dalam kegiatan bisnis. Peran modal dalam bisnis adalah pentiing karena merupakan alat untuk produksi barang dan jasa.

Menurut UU No. 13 Tahun 2003 tentang Ketenagakerjaan, pengertian tenaga kerja adalah setiap orang yang mampu melakukan pekerjaan guna menghasilkan barang dan atau jasa baik untuk memenuhi kebutuhan sendiri maupun kebutuhan masyarakat. Simanjuntak (1985) mengungkapkan bahwa teori permintaan tenaga kerja merupakan teori yang menjelaskan seberapa banyak perusahaan tersebut akan mempekerjakan tenaga kerja dengan berbagai tingkatupah dalam suatu periode tertentu.

Menurut UU No. 13 Tahun 2003 tentang Ketenagakerjaan, jam kerja adalah waktu untuk melakukan pekerjaaan, yang dapat dilaksanakan siang hari atau malam hari. Waktu kerja adalah jumlah waktu yang digunakan untuk menjalankan bisnis, dari persiapan hingga akhir bisnis. Sering dapat diasumsikan bahwa "semakin banyak waktu kerja yang digunakan, semakin produktif." Ini berarti bahwa jam kerja yang lebih lama secara tidak langsung akan membuat pekerjaan lebih produktif dan menghasilkan pendapatan besar.

Pendapatan adalah total penghasilan yang diperoleh dari pekerjaan, biasanya nilai dari penghasilan seseorang dihitung setiap tahun atau setiap bulanan. Menurut Boediono (2002) secara garis besar pendapatan digolongkan menjadi tiga, yaitu:

1. Gaji adalah upah dimana yang diterima sesorang setelah bekerja untuk orang lain dalam sehari, seminggu, atau juga sebulan.

2. Penghasilan perusahaan milik sendiri adalah nilai produk bruto setelah adanya pengurangan biaya yang dibayarkan, dan perusahaan itu adalah perusahaan milik sendiri atau milik keluarga. Nilai sewa dari modal sendiri dan semua pengeluaran ini biasanya tidak termasuk.

3. Penghasilan dari bisnis lain, yaitu pendapatan lain yang diperoleh tanpa menggunakan faktor tenaga kerja,yang merupakan pendapatan insidentil, yang mencakup pendapatan dari asset baik berupa leasing, bunga dari mata uang, sumbangan dari pihak lain, pendapatan pensiun, dan lain-lain.

\section{Hipotesis}

Diduga sementara penelitian ini, yaitu:

1. Diduga variabel modal, tenaga kerja, dan jam kerja secara parsial berpengaruh terhadap pendapatan pedagang di Pasar Modern Puncak Permai Tahun 2019.

2. Diduga variabel modal, tenaga kerja, dan jam kerja secara simultan berpengaruh terhadap pendapatan pedagang di Pasar Modern Puncak Permai Tahun 2019.

\section{Metode Penelitian}

Jenis penelitian ini menggunakan pendekatan kuantitatif yang menekankan pada pengujian hipotesis, data yang penggunaannya harus dapat diukur dan akan menghasilkan suatu kesimpulan yang dapat di generalisasikan. Jumlah populasi yang digunakan dalam penelitian 
ini adalah seluruh pedagang yang ada di Pasar Modern Puncak Permai yang berjumlah 350 pedagang. Pengambilan atas sampel pada penelitian ini menggunakan metode Simple Random Sampling yaitu pengambilan secara acak. Jumlah sampel yang digunakan dengan menggunakan rumus slovin sebesar 78 pedagang.

Pengumpulan data yang ada pada penelitian ini menggunakan survei lapangan, kuesioner dan studi kepustakaan. Survei lapangan dengan melakukan penelitian, pengamatan dan peninjauan secara langsung ke Pasar

Modern Puncak Permai. Kuesioner survei mencakup survei terbuka dan tertutup yang digunakan untuk mencari modal, tenaga kerja, jam kerja, dan pendapatan di Pasar Modern Puncak Permai. Studi kepustakaan melalui membaca literatur, buku dan jurnal yang berkaitan.

Definisi operasional variabel dalam penelitian ini terdapat variabel bebas yaitu modal, tenaga kerja, dan jam kerja terhadap variabel terikat yaitu pendapatan pedagang di Pasar Modern Puncak Permai Surabaya.Teknik analisis data dalam penelitian ini dengan mengunakan pendekatan analisis regresi linier berganda cross section. Teknik analisis menggunakan uji asumsi klasik yang terdiri dari pengujian linearitas, uji multikolinieritas, uji heteroskedastisitas, uji autokorelasi, uji normalitas. Pengujian dengan uji hipotesis yang terdiri dari uji T (parsial), Uji F (simultan), dan Uji Koefisien Determinasi (R2).

\section{Hasil}

\section{Analisis Deskriptif}

Diperoleh nilai rata-rata dari presentase pendapatan yang diperoleh pedagang di Pasar Modern Puncak Permai tiap bulan sebesar Rp 26.346.154. Nilai median dari pendapatan pedagang Pasar Modern Puncak Permai sebesar Rp 27.000.000, serta nilai tertinggi sebesar Rp 52.000.000 dan nilai konsentrasi pendapatan terendah sebesar Rp 15.000.000 dengan nilai standar deviasi sebesar Rp 7.728.892. Nilai mean yang diperoleh lebih besar dari nilai standar deviasi, maka dapat disimpulkan bahwa rata-rata dari seluruh data variabel pendapatan (Y) mampu menggambarkan seluruh data variabel pendapatan $(\mathrm{Y})$ dengan baik.

Modal (X1) memiliki rata-rata sebesar Rp 23.192.308 dengan nilai median sebesar Rp 21.500.000. Pada nilai tertinggi sebesar Rp 45.000.000 dan nilai terendah sebesar Rp 7.000.000. Dari data diatas standar deviasi varibel modal sebesar Rp 6.826.339. Nilai mean yang diperoleh lebih besar dari nilai standar deviasi, maka dapat disimpulkan bahwa rata-rata dari seluruh data pada variabel modal (X1) mampu menggambarkan seluruh data variabel modal (X1) dengan baik.

Tenaga Kerja (X2) memiliki rata-rata sebesar 3,397436 dengan nilai meannya sebesar 3,000000. Tenaga kerja tertinggi sebesar 5,000000 dan tenaga kerja terendah sebesar 2,000000 . Standar deviasi pada variabel tenaga kerja sebesar 1,132056. Variabel tenaga kerja (X2) memiliki nilai mean yang lebih besar dari nilai standar deviasi, maka dapat disimpulkan bahwa rata-rata dari seluruh data pada variabel tenaga kerja (X2) mampu menggambarkan seluruh data variabel tenaga kerja (X2) dengan baik.

Jam kerja (X3) memiliki rata-rata sebesar 7,589744 dengan nilai median sebesar 8,000000. Jam kerja tertinggi sebesar 9,000000 dan jam kerja terendah sebesar 6,000000. Standar deviasi pada variabel jam kerja sebesar 1,121640. Variabel jam kerja (X3) memiliki nilai mean yang lebih besar dari nilai standar deviasi, maka dapat disimpulkan bahwa rata-rata dari seluruh data pada variabel jam kerja (X3) menggambarkan seluruh data variabel jam 
kerja $(\mathrm{X} 3)$ dengan baik. Pendapatan $=-122887,2+0,615779$ Modal +2436698 Tenaga Kerja + 515060.5 Jam Kerja

\section{Uji Linearitas}

Uji linearitas dilakukan untuk menghindari terjadinya specifation error. Uji linearitas dilakukan untuk mendeteksi bentuk model empiris yang peneliti gunakan sudah benar atau tidak dan menguji apakah suatu variabel baru relevan atau tidak dimasukkan dalam model empiris. Uji linearitas dalam penelitian ini menggunakan Ramsey RESET test.

Hasil uji linearitas dengan Ramsey RESET Test menunjukkan bahwa dalam model tidak terdapat permasalahan linearitas atau model yang digunakan dalam bentuk linier. Hal ini ditunjukkan dengan nilai F-statistik sebesar 1,989 < F-tabel sebesar 2,16 dengan nilai numerator $3(4-1=3)$ dan denumerator 74 (78-4=74) dengan $\alpha=10 \%$. Selain itu peneliti dapat mempertimbangkan nilai Probability F- statistic sebesar 0,1627 >0,10 atau $\alpha=10 \%$.

\section{Uji Multikolinieritas}

Uji multikolinieritas merupakan pengujian untuk mengetahui apakah pada model regresi terdapat korelasi antar variabel independen. Pengujian ini juga penting untuk mengetahui tidak adanya kemiripan antar variabel independen dalam satu model. Dalam penelitian ini menggunakan Variance Inflatin Factor (VIF) dan nilai Tolerance.

Perhitungan mengunakan VIF :

$$
\begin{aligned}
V I F & =\frac{1}{1-0,5913} \\
& =\frac{1}{0,4087} \\
& =2,44678
\end{aligned}
$$

Melihat hasil perhitungan VIF dan TOL diatas dapat disimpulkan bahwa permodelan yang dibangun tidak terdapat suatu permasalahan multikolinearitas karena memiliki nilai VIF kurang dari 10 sehingga dapat disimpulkan bahwa dari ketiga variabel tersebut tidak mengalami masalah multikolinieritas.

\section{Uji Heteroskedastisitas}

Uji heteroskedastisitas untuk menguji apakah dalam model regresi terjadi ketidaksamaan varian dari residual satu pengamatan ke pengamatan yang lain. Model regresi yang baik adalah yang homoskedastisitas atau tidak terjadi heteroskedastisitas.

Berdasarkan hasil dari estimasi dengan menggunakan Breusch-Pagan-Godfrey Test, hasil tersebut menunjukkan nilai probabilitas X2 hitung (Obs*R-squared) sebesar 0,3843> $\alpha$ $=10 \%$ atau $(0,10)$ dapat dilihat dari hasil ini menunjukkan tidak terdapat permasalahan heteroskedastisitas.

\section{Uji Autokorelasi}

Autokorelasi terjadi apabila nilai error term dalam periode tertentu berhubungan dengan nilai error term sebelumnya. Untuk melihat ada tidaknya penyakit autokorelasi dapat juga digunakan uji (Langrange Multiplier) LM dengan membandingkan probabilitas R-Squared dengan $\alpha=10 \%$.

Pada uji BG-LM test yang diperhatikan adalah nilai dari probabilitas (Obs*Rsquare) 
sebesar $0,1111>$ nilai probabilitas kritis $\alpha=10 \%$, yang berarti model tidak mengalami masalah autokorelasi. Hasil dari BG-LM test menunjukkan bahwa dalam model penelitian ini tidak terdapat permasalahan autokorelasi

\section{Uji Normalitas}

Pengujian normalitas dengan menggunakan pendekatan uji Jarque-berra Test dengan syarat apabila nilai JB hitung < nilai X2 -tabel maka hipotesis yang mengatakan bahwa residual, ut merupakan berdistribusi normal diterima.

Berdasarkan hasil analisis dapat diketahui bahwa nilai probabilitas JB hitung sebesar $0,752788>$ nilai probabilitas kritis $\alpha=0,10(10 \%)$. Hasil tes menunjukkan bahwa dalam model penelitian tidak terdapat permasalahan normalitas. Sehingga dapat disimpulkan bahwa residual terdistribusi normal yang artinya asumsi klasik tentang kenormalan telah dipenuhi.

\section{Uji t (parsial)}

Fungsi uji t adalah uji yang digunakan untuk melihat signifikansi parameter bebas yang dapat dijelaskan oleh variabel terikat. Apabila nilai t-hitung $>$ t-tabel atau probabilitas t-hitung $<$ nilai probabilitas kritis $\alpha=0,10(10 \%)$. Hal ini berarti variabel bebas $(X)$ signifikan berpengaruh terhadap variabel terikat $(\mathrm{Y})$.

Hasil regresi yang telah dilakukan dapat dilihat dari tabel diatas yang menunjukkan hubungan pengaruh variabel independent modal (X1), tenaga kerja (X2), dan jam kerja (X3) terhadap variabel dependent yakni pendapatan $(\mathrm{Y})$ sebagai berikut :

1. Nilai t-hitung variabel modal $>$ t-tabel yaitu sebesar $6,840579>1,668$ atau nilai probabilitas variabel modal t-hitung $<$ nilai probabilitas kritis $(\alpha=10 \%)$ sebesar $0,0000<0,10$ sehingga variabel bebas modal (X1) berpengaruh signifikan atau berpengaruh positif terhadap variabel pendapatan pedagang di Pasar Modern Puncak Permai.

2. Nilai t-hitung variable tenaga kerja $>\mathrm{t}$ - tabel yaitu sebesar $4.426658>1,668$ atau nilai probabilitas variabel tenaga kerja t- hitung < nilai probabilitas kritis $(\alpha=10 \%)$ sebesar $0,0000<0,10$ sehingga variabel bebas tenaga kerja (X2) berpengaruh signifikan atau berpengaruh positif terhadap variabel terikat pendapatan pedagang di Pasar Modern Puncak permai.

3. Nilai t-hitung variabel jam kerja $<\mathrm{t}$-tabel yaitu sebesar $0,994565<1,668$ atau nilai probabilitas variabel jam kerja t-hitung $>$ nilai probabilitas kritis $(\alpha=10 \%)$ sebesar $0.3232>0,10$ sehingga variabel bebas jam kerja (X3) berpengaruh tidak signifikan terhadap variabel terikat pendapatan pedagang di Pasar Modern Puncak Permai.

\section{Uji F (simultan)}

Uji F digunakan untuk mengetahui apakah variabel-variabel independen secara simultan berpengaruh signifikan terhadap variabel dependen.

Nilai prob. F-Statistik sebesar $0,000000<\alpha=0,10$ atau (10\%) dan nilai F-Statistik $>$ F-Tabel sehingga dapat disimpulkan bahwa model regresi yang diestimasi mampu untuk digunakan dalam menjelaskan pengaruh hubungan variabel bebas modal (X1), tenaga kerja (X2), dan jam kerja (X3) terhadap variabel terikat pendapatan (Y) secara simultan atau secara keseluruhan variabel bebas modal $(X 1)$, tenaga kerja (X2, dan jam kerja (X3) berpengaruh secara signifikan terhadap variabel terikat pendapatan $(\mathrm{Y})$. 


\section{Koefisien Determinasi (R2)}

Koefisien determinasi menjelaskan variasi pengaruh variabel-variabel bebas terhadap variabel terikatnya atau dapat pula dikatakan sebagai proporsi pengaruh seluruh variabel bebas terhadap variabel terikat.

Nilai Adjusted R-squared pada tabel di atas sebesar 0.591330 yang menunjukkan bahwa proporsi pengaruh variabel bebas modal (X1), tenaga kerja (X2), dan jam kerja (X3) terhadap variabel terikat pendapatan $(Y)$ sebesar 59,13 persen sedangkan sisanya 40,87 persen dipengaruhi oleh variabel lain yang tidak ada didalam model regresi.

\section{Diskusi}

\section{Pengaruh Modal (X1), Tenaga Kerja (X2), dan Jam Kerja (X3) Secara Parsial dan Simultan Terhadap Pendapatan Pedagang di Pasar Modern Puncak Permai.}

Berdasarkan hasil uji t untuk variabel modal (X1) dan variabel tenaga kerja (X2) dapat diketahui t-hitung lebih besar dibandingkan t- tabel dengan nilai signifikan lebih kecil dari 0,10. Hal ini menunjukkan bahwa variabel modal (X1) dan juga tenaga kerja (X2) berpengaruh secara parsial terhadap variabel dependen pendapatan (Y). Sedangkan untuk variabel jam kerja (X3) dapat diketahui t-hitung lebih kecil dibandingkan t-tabel dengan nilai tidak signifikan lebih besar dari 0,10. Hal ini menunjukkan bahwa secara parsial jam kerja (X3) tidak berpengaruh terhadap variabel pendapatan (Y). Berdasarkan hasil uji F menunjukkan bahwa nilai F-hitung > nilai F- tabel atau nilai prob. F-hitung $<\alpha=10 \%$, bahwa variabel modal (X1), tenaga kerja (X2), dan jam kerja (X3) berpengaruh secara simultan terhadap pendapatan (Y). Dari hasil analisis regresi berganda yang telah dilakukan, maka dapat diketahui bahwa:

1. Variabel bebas modal (X1) menunjukkan terdapat pengaruh terhadap variabel terikat pendapatan $(\mathrm{Y})$ yang positif dengan nilai prob. $0,0000<\alpha=10 \%$ atau 0,10 sehingga variabel bebas modal (X1) berpengaruh positif terhadap variabel terikat pendapatan (Y). Hasil koefisien regresi modal (X1) sebesar 0,615779 menunjukkan bahwa setiap nilai variabel modal (X1) bertambah sebesar 1 rupiah maka variabel terikat pendapatan $(\mathrm{Y})$ akan mengalami kenaikan sebesar 0,615779 rupiah. Hasil dari penelitian menunjukkan bahwa modal berpengaruh positif signifikan terhadap pendapatan, dimana jika modal meningkat maka pendapatan juga akan dapat mengalami peningkatan.

2. Variabel bebas tenaga kerja (X2) menunjukkan bahwa terdapat pengaruh terhadap variabel terikat pendapatan $(Y)$ yang positif dengan nilai prob. $0,0000<\alpha=10 \%$ atau 0,10 sehingga variabel bebas tenaga kerja (X2) berpengaruh positif terhadap variabel terikatnya yaitu pendapa$\tan (\mathrm{Y})$. Hasil koefisien regresi tenaga kerja (X2) sebesar 2436698. yang menunjukkan bahwa setiap nilai tenaga kerja (X2) bertambah sebesar 1 orang maka variabel terikat pendapatan (Y) akan mengalami kenaikan sebesar 2.436 .698 rupiah. Hasil penelitian juga menunjukkan bahwa tenaga kerja berpengaruh positif signifikan terhadap pendapatan. Dengan adanya peningkata tenaga kerja maka pedagang akan meningkatkan pula jumlah produksinya. Apabila jumlah produksi meningkat maka banyak produk yang terjual sehingga pendapatan juga ikut meningkat.

3. Variabel bebas yakni jam kerja (X3) menunjukkan tidak berpengaruh tehadap variabel terikat pendapatan $(\mathrm{Y})$ yang positif dengan nilai prob. $0,3232>\alpha=10 \%$ atau 0,10 sehingga variabel bebas jam kerja (X3) tidak memiliki pengaruh terhadap variabel terikat pendapatan (Y). Hasil koefisien regresi jam kerja (X3) sebesar 515060,5 yang menunjukkan bahwa naik turunnya nilai jam kerja (X3) tidak akan berpengaruh terhadap nilai variabel pendapatan (Y). 
4. Nilai kontanta sebesar $-122887,2$. Hal ini menunjukkan terjadi penurunan terhadap variabel pendapatan jika variabel bebas modal (X1), tenaga kerja (X2), dan jam kerja (X3) dianggap konstan.

\section{Simpulan}

Berdasarkan hasil analisis data tentang pengaruh modal, tenaga kerja, dan jam kerja terhadap pendapatan pedagang di Pasar Modern Puncak Permai, maka dapat diperoleh kesimpulan sebagai berikut:

1. Modal memiliki pengaruh terhadap pendapatan pedagang di Pasar Modern Puncak Permai di tahun 2019.

2. Tenaga kerja memiliki pengaruh terhadap pendapatan pedagang di Pasar Modern Puncak Permai di tahun 2019.

3. Jam kerja tidak memiliki pengaruh terhadap pendapatan pedagang di Pasar Modern Puncak Permai di tahun 2019.

4. Secara simultan modal, tenaga kerja, dan jam kerja berpengaruh terhadap pendapatan pedagang di Pasar Modern Puncak Permai Tahun 2019.

\section{Saran}

Berdasarkan hasil penelitian maka saran yang dapat diambil dari penelitian ini adalah sebagai berikut:

1. Diharapkan bagi para pedagang di Pasar Modern Puncak Permai untuk dapat memperhatikan faktor lainnya selain dari tiga faktor yang diteliti yaitu modal, tenaga kerja dan jam kerja dan juga tetap dapat mempertahankan dan juga meningkatkan faktor-faktor yang memiliki pengaruh terhadap tingkat pendapatan pedagang.

2. Bagi pengelola pasar, pengelola pasar harus mulai berkoordinasi dengan para pedagang di Pasar Modern Puncak Permai untuk dapat mendapatkan pengelolahan pasar yang lebih baik.

3. Untuk peneliti selanjutnya, hasil penelitian ini bisa digunakan sebagai referensi bagi peneliti selanjutnya dengan menambah variabel lebih banyak atau dengan teknik analisis yang berbeda.

\section{Daftar Pustaka}

Boediono. (2002). Ekonomi Makro: Seri Sinopsis Pengantar Ilmu Ekonomi No.1 Edisi 2. Yogyakarta: BPEE

Damayanti, Ifany. (2011). Analisis Faktor- Faktor Yang Mempengaruhi Pendapatan Pedagang Di Pasar Gede Kota Surakarta. Skripsi. Fakultas Ekonomi Universitas Sebelas Maret : Surakarta.

Firdausa, Rosetyadi Artistyan. (2013). Pengaruh Modal Awal, Lama Usaha Dan Jam Kerja Terhadap Pendapatan Kios Di Pasar Bintoro Demak. Skripsi. Fakultas Ekonomika Dan Bisnis Universitas Diponegoro: Semarang.

Gregory N, Mankiw. 2011. Principles of Economics (Pengantar Ekonomi Mikro). Jakarta: Salemba Empat 
Kusumawardani, Yanuarti Dwi. (2019). Analisis Pengaruh Modal, Jam Kerja, Lama Usaha, Dan Lokasi Usaha Terhadap Pendapatan Pedagang. Skripsi. Fakultas Ekonomi Dan Bisnis Universitas Wijaya Kusuma : Surabaya.

Ma'arif, Samsul. (2013). Analisis Faktor-Faktor Yang Mempengaruhi Pendapatan Pedagang Pasar Bandarjo Unguran Kabupaten Semarang. Skripsi. Jurusan Ekonomi Pembangunan Fakultas Ekonomi Universitas Negeri Semarang: Semarang.

Maghfira, Afrah Nabila dkk. (2018). Pengaruh Modal, Jam Kerja, dan Lama Usaha Terhadap Pendapatan Pedagang Ikan Hias di Pasar Ikan Mina Restu di Desa Purwanegara Kecamatan Purwokerto Utara. Jurnal Ekonomi, Bisnis, dan Akuntansi. Vol. 20 No. 04.

Mankiw N,Gregory, dkk. (2012), Pengantar Ekonomi Makro. Jakarta: Salemba Empat.

Ma'rufaa, Laili Riziiq. (2017). Pengaruh Modal Usaha, Tenaga Kerja, Jam Kerja, dan Lama Usaha Terhadap Pendapatan Usaha Counter Pulsa di Kecamatan Gresik. Skripsi. Fakultas Ekonomi Dan Bisnis Universitas Muhammadiyah Gresik: Gresik.

Nurfiana, Ike Wahyu. (2018). Analisis Pengaruh Modal, Jam Kerja, Dan Lokasi Terhadap Tingkat Pendapatan Pedagang Pasar Mranggen. Skripsi. Fakultas Ekonomi Dan Bisnis Islam Universitas Islam Negeri Walisongo: Semarang.

Pratomo, Gigih dan Kristiyanto, Sony. (2015). Modul Laboratorium Ekonometrika Aplikasi E-views Dalam Model Analisis Ekonomi Dan Bisnis 1. Surabaya: Fakultas Ekonomi Pembangunan Universitas Wijaya Kusuma.

Riyanto, Bambang. (1998). Dasar-Dasar Pembelanjaan Perusahaan. Yogyakarta: Yayasan Badan Penerbit Gajah Mada.

Rohmah, Safaatur. (2017). Faktor-Faktor Yang Mempengaruhi Tingkat Pendapatan Pedagang Pasar Juwana Baru Kabupaten Pati. Skripsi. Jurusan Ekonomi Pembangunan Fakultas Ekonomi Universitas Negeri Semarang: Semarang.

Simanjuntak, Payaman. (1985). Pengantar Ekonomi Sumber Daya Manusia. Jakarta: Lembaga Penerbit Fakultas Ekonomi Universitas Indonesia.

Simanjuntak, Payaman. (2001). Ekonomi Sumber Daya Manusia. Jakarta: Lembaga Penerbit Fakultas Ekonomi Universitas Indonesia.

Sugiyono. (2013). Metode Penelitian Pendidikan Pendekatan Kuantitatif, Kualitatif, dan R\&D. Bandung: Alfabeta

Suprapti, Ervin. (2017).Pengaruh Modal, Umur, Jam Kerja Dan Pendidikan Terhadap Pendapatan Pedagang Perempuan Pasar Barongan Bantul. Skripsi. Program Studi Pendidikan Ekonomi Universitas Negeri Yogyakarta: Yogyakarta.

Undang-Undang Republik Indonesia Nomor 13 Tahun 2003 Tentang Ketenagakerjaan.

Wahyono, Budi. (2017). Analisis Faktor-faktor Yang Mempengaruhi Pendapatan Pedagang Di Pasar Bantul Kabupaten Bantul. Skripsi. Program Studi Ekonomi Fakultas Ekonomi Universitas Negeri Yogyakarta: Yogyakarta.

Wirakusuma, Ida Bagus Gede dkk. (2018). Pengaruh Modal, Tenaga Kerja, dan Jam Kerja Terhadap Pendapatan Pedagang Babi Guling di Kecamatan Kerambitan. Majalah Ilmiah Fakul- 
Yustie, R. \& Retnowati, I Determine The Effect of Capital, Labor, and Working Permai Modern Market in 2019 rabaya Puncak

tas Ekonomi Universitas Tabanan. Vol. No. 1. 